\title{
Human resource management in a siege economy
}

\author{
F.M. Horwitz \\ Graduate school of Business, University of Cape Town, Rondebosch, 7700 Republic of South Africa
}

Accepted 2 February 1987

\begin{abstract}
There is a paucity of published work on the implications of a siege economy in South Africa on the management of human resources. Existing organizational policies and strategies may be inadequate in coping with rapid environmental change and a high degree of uncertainty. This paper focuses on an identification of cxtra- and intraorganizational demands which could confront the business sector and individual companies in the next three to five years. A critical analysis of these demands is offered. Recommendations and conclusions are provided in respect of the strategic adaptive responses required by organizations.
\end{abstract}

Daar is ' $n$ tekort aan gepubliseerde werke oor die implikasies van ' $n$ belegsekonomie in Suid-Afrika vir die bestuur van menslike hulpbronne. Bestaande organisasiebeleid en strategie mag nie geskik wees om vinnige omgewingsveranderinge en 'n hoë graad van onsekerheid te hanteer nie. Hierdie artikel beklemtoon die identifikasie van buite- en binne-organisasievereistes wat die besigheidsektor en individuele maatskappye kan konfronteer binne die volgende drie tot vyf jaar. 'n Kritiese ontleding oor hierdie vereistes word aangebied. Aanwysings en gevolgtrekkings word gegee in verband met strategiese aanpassings wat deur organisasies vereis word.

'Where there is no vision, the people perish.'

Proverbs Ch 29, 18 .

\section{Introduction}

Human resource strategies in South Africa will have to extend beyond that of the effective acquisition and development of manpower and establishment of sound labour relations within organizations, to dealing with extra-organizational environmental issues, particularly the quality of life of communities in which employees live and influence on socio-political change.

\section{The siege economy}

Certain assumptions are made in seeking to define the contribution of human resource management under siege circumstances. Whilst the assumptions are suggestive of a particular scenario and are based on an evaluation of current developments and literature, they should be regarded as tentative given the uncertainty prevalent in the South African context. This makes definitive predictions implausible.

The siege economy could reveal a number of characteristics. These incude to a varying extent, the following:

- Declining market demand for 'non-essential' goods owing to boycotts, partial or full disinvestment by foreign companies and varying degrees of trade sanctions. (Between January 1985 and July 1986, 55 United States companies out of a total of 312 withdrew from South Africa.) (Business Day, July 24, 1986.)

- Higher prices and shortages of certain consumer and other goods owing to demand reduction and raw material importation difficulties.

- Continued high inflation rates and declining living standards.

- Increasing retrenchments and consequent higher unemployment of all races. However, technically skilled manpower shortages may continue in certain occupations, and redeployment of employees between sectors may occur. The informal sector could also be stimulated with more urbanization occurring due to changes in the system of influx control. A steady efflux from the country of managerial and professional manpower in spite of the weak Rand, will continue.

- Lack of meaningful investment in human resource training and development owing to cost constraints.

- Continuing large disparities in wealth and opportunity between race groups and between employed and unemployed.

- Heightened attitudinal polarization at macro-levels and intra-organizationally, amongst employees.

- Increased concern for personal and institutional security with a siege mentality becoming more predominant.

- Increased militarization of society and more frequent and possibly longer military call-ups having adverse affects on business productivity. The notion of a military dictatorship becomes more ominous as ad hoc reforms are unable to diffuse rising expectations, bitterness, and suppressed anger. Van Zyl Slabbert (1986) posits that the pattern of present politics would evolve along the lines of a multi-racial autocracy. This system would reflect a removal of racial discrimination, but would have a coercive orientation focused on the maintenance of stability and law and order. The issues of power transfer or power sharing would not be properly addressed and the system would be perceived as being in juxtaposition to the struggle for freedom.

- A high degree of political rhetoric by various organizations across the political spectrum which may also reflect attempts at pre-negotiation power building.

- Reduced levels of organizational commitment by employees.

- Continuing protests and demonstrations as manifested by work stay-aways and consumer boycotts. 
The above list is not exhaustive. It suggests that innovative human resource strategies are urgently required at macro-institutional level such as Government and employer associations. Numerous extra-organizational demands in the environment which adversely affect the business sector, individual companies and employer organizations will necessitate proactive strategically developed rather than reactive ad hoc responses to specific issues.

The business sector has the knowledge and experience to lead change both within individual companies and as sponsors or agents of what Godsell (1986) referred to as public collective bargaining. Clearly, however, the development of human resources philosophies policies and strategies for organizations to accommodate macro- and micro-environmental demands, has never been as vital as it will be over the next three to four years.

\section{Crisis in expectations}

The acquisition of the industrial franchise by black workers has resulted in a greater democratization of the work place. Over 800 recognition agreements between employers and trade unions have been negotiated since the extension of freedom of association was made to black employees by the Industrial Conciliation Amendment Act in 1979. The process of institutionalizing conflict through collective bargaining and procedural accomodation, has given black and white employees meaningful negotiation experience in industry and commerce. Industrial disputes have more often than not been resolved through negotiated compromise.

However the siege economy will inter alia, largely have been a consequence of a failure to enter into a similar process of negotiation resulting in the granting of an acceptable political franchise to the majority of the country's population. A crisis and conflict of expectations amongst black employees has arisen as a result. The absence of a political franchise has resulted in increasing politicization of the work place, with stayaways and racial polarization becoming serious concerns. Of particular concern in the context of the state of emergency and a siege economy is an undermining of the sound platform for negotiated compromise on industrial relations issues by the detention of trade union leaders.

The crisis of expectations is exacerbated by the government's espoused policy of moving towards more free enterprise, less intervention in the economy and negotiated political solutions which are contradicted by its actions in introducing a state of emergency; detentions of black leaders, restrictions on press freedoms and other civil liberties, and increased societal militarization.

Over 200 elected union leaders and 1319 rank and file members were detained during June and July 1986. (Labour Monitoring Group, July 1986). The resultant demonstration strikes in several sectors including retail and mining, reflected increased bitterness and resentment and an erosion of what middle ground has been painstakingly built up in labour relations in the early and mid1980 s.

Similarly, Kantor (1986) argues that the threat and fact of sanctions will increase the mobility of professional and skilled manpower, leading to a shrinkage of the middle ground. This uncertainty is damaging to confidence and forward planning.

There are currently some 350000 black people from other countries legally employed in South Africa. Should Government as a response to sanctions, seek to reduce the present high levels of unemployment (over the last 10 years 291000 jobs have been lost in construction and manufactoring alone) (Sunday Times, June 29, 1986:28) by repatriating well-trained and experienced foreign workers, most observers, according to D'Oliveira (1986) 'believe that it is highly unlikely that this will prevent the West from imposing further sanctions', which in turn could increase unemployment and the country's isolation. Whilst many of the foreign workers are in relatively unskilled and semi-skilled jobs in major industries such as mining, the recruitment and training cost of taking on South African workers as replacements will present major difficulties in respect of the country's resources and could also generate added tensions in that newly employed replacements may be split from their families. A revised or quasi-migrant labour system with attendant socio-political problems, would evolve. If under these circumstances sanctions are intensified, business confidence will be further undermined. With estimates of unemployment ranging from $12,5 \%$ to over $30 \%$ of the black population, and more than 300000 people coming on to the labour market every year (Beeton, 1986:22), the psychological, social and political consequences of unemployment and lack of job creation, are an obvious danger to the fabric of our society. If the free enterprise system is associated by employees with mass scale retrenchments and consequent unemployment and poverty, it is not surprising that as found by Project Free Enterprise (1986) black people feel they have no stake in a system which is seen as a collaborating with Apartheid.

\section{Manpower policies}

Employers seriously need to re-examine their manning and employment philosophies to seek ways of enhancing job security. Manpower planning has proved unsuccessful in South Africa in respect of establishing relatively stable manpower levels across business cycles. A search for the optimum balance between an organization's economic and financial objectives and that of its social responsibility to the environment in which it operates, and to its employees, is vital.

One of the major criticisms of manpower planning in the South African context is that surplus manpower tends to be highlighted only during an economic downturn and action which is frequently arbitrary and of a short-term emergency nature, is taken to reduce the surplus. Rarely is the question of effective manpower level control addressed during an economic upswing, with recruitment drives including the importation of skilled manpower from abroad aimed at raising manpower strengths typifing economic upswings whilst significant reductions occur during downturns. The siege economy will, however, not prove attractive for potential overseas 
recruits. This must provide an added incentive for the training and development of existing employees with identified potential for advancement. In addition managers should be given directives to smooth out peaks and valleys in company employment levels to minimize wide fluctuations in the labour force. This would be rewarded by gains in enhanced community relations, reduced recruiting and training costs and reduced retrenchment payment costs. The threat of mass unemployment to societal stability is exacerbated by the inadequate social security system in South Africa. At a macro-level, employer organizations and the State should seriously review their social policies in respect of unemployment insurance and medical schemes. There is virtually no effective economic cushion which alleviates the emotional and physical trauma of prolonged periods of unemployment as in Western countries such as the United States and the United Kingdom. Job-creation schemes must receive urgent priority by the State and the business sector. Joint projects and collaboration in this area together with organized labour should be considered.

According to a study by Nel, (1986:24-25), an estimated one million jobs could be lost if total sanctions were imposed. Nel argues that if, in addition to current levels of unemployment, a further 600000 black people were retrenched, $31,9 \%$ of all economically active blacks would be out of work. Even if these figures were an exaggeration and redeployment of substantial numbers of employees was feasible, sanctions could in the short term have an adverse impact on employment levels. It is possible, however, that with increasing urbanization and the removal of some aspects of influx control, growth of the informal economic sector could be stimulated. (The combination of the Aliens Act, Restoration of Citizenship Act and the Group Areas and Prevention of Illegal Squatting Acts will, however, ensure that a modified form of influx control will continue. The prospect of rising unemploymet will pose a major challenge in creating some 6,8 million new jobs by the year 2000 if 'Black employment levels' are to attain the same state as 'White employment levels' according to Nel. An analysis of job creation from 1950 to 1985 shows that only from 1960 to 1970 when economic growth averaged 5,9\%, did employment equal population growth. In four of the past five years to 1986, economic growth was in fact negative. The development of import substitution would to some degree offer alternative employment for retrenched employees from sectors heavily reliant on imported materials and components. However, the precise impact of economic sanctions on employment levels and job creation opportunities is difficult to estimate given that they will certainly have social and political consequences. The fatalistic approach in recent statements by government spokesmen towards sanctions and their implications, coupled with the erosion of civil liberties by the state of emergency are cause for serious concern.

In a recent announcement, the Chamber of Mines stated that $35 \%$ of the coal mining sector's $110000 \mathrm{em}$ ployees' jobs could be in jeopardy if the call for total sanctions in the European Parliament was successful.
The impact of deteriorating coal demand arising from decisions by Denmark to ban coal imports from South Africa and reduced exports to France and other countries could have an adverse effect on industrial relations and the livelihoods of employees and their dependents, even if the consequences of sanctions have been ex. aggerated.

In a siege economy with full or even partial sanctions, the immediate challenge of merely maintaining employment levels and preventing further reductions in these levels will probably assume greater priority than employment creation and absorption of increasing numbers of people into economic activity. Companies, despite pressures on costs, and particularly manpower costs, should nevertheless explore possibilities of engaging in profitable labour intensive forms of production and materials handling. However, although laudible efforts are being made to stimulate the small business and informal sectors, there are disturbing indications that an increasing number of companies are, because of an inability to successfully cope with industrial relations problems, seeking to move towards capital rather than labour intensive activities. These moves, while improving efficiency, will not facilitate greater acceptance of the free enterprise system amongst black employees and could arguably raise doubts about the social responsibility of such organizations. As Leatt, (1984:1) said 'Capitalism is what capitalism does'. Even moderate black capitalist opinion seems to have hardened recently with an employers organization such as the National African Federated Chamber of Commerce (NAFCOC) stating that it is reviewing its opposition to sanctions. Van der Watt (1983) aptly stated that 'it is all too easy to give up all hope and immerse oneself in detailed practicalities, with both eyes on the balance sheet and no view to the future'.

\section{Other environmental demands}

The siege economy is likely to continue with high double digit inflation rates. Official figures reflect a frightening increase in the costs of basic goods and services. In the year ended May 1986 tea and coffee increased by over $33,3 \%$, medical care by $25 \%$ and meat and fish over $20 \%$ (The Argus, July 2, 1986:14). The pressure on trade unions to seek above inflation rate increases in an attempt to halt and reverse declining living standards, will continue in spite of an over-supply of unskilled labour. This, coupled with the hardened political attitudes associated with the state of emergency and detentions of union leaders will severly test the viability of the postWiehahn labour relations dispensation and the day-today relations between management and employees.

According to Oosthuizen (1986) there would be between 8 and 10 million more urbanized black people by the year 2000 than at present. Whilst job security protection will become even more vital in this uncertain environment, a further issue which will also concurrently become more prominent is a concerted demand from black employees and their trade unions for a move away from talking about black advancement towards specific corporate objectives and practical implementation plans 
with target achievement dates. Employers will have to be seen to be giving preference to the training and advancement of employees from within the organsiation rather than recruiting from outside when suitable internal candidates are available. In addition, manning structures of organizations should be critically reviewed to facilitate a shift away from the exclusive occupation of unskilled and semi-skilled positions by black people. Companies will need to develop strategies to reduce racial polarization of the work-force in order to achieve both business objectives and visible fairness in the work place. One objective towards this end should be the restructuring of the work-force to ensure that a multi-racial mix of employees occurs at all organizational levels. With increasing urbanization and possible removal or major changes to the Group Areas Act, innovative housing and accommodation strategies will also have to be developed by employers, employer organizations and the State.

\section{Strategy formulation}

Austin \& Ickis (1986) in a study of the survival strategies of multinational companies in a South American revolutionary climate, contend that a special and conscious effort is required in respect of the development of adaptative managerial thinking, an ability to redefine and adjust strategies and to carve out new relationships with key interest groups. In the South African context, the securing of the long-term interests and developing of our human resources must be facilitated by a pro-active role of business leaders in forging relationships with trade unions, community and political organizations. It is contended that the styles of managerial leadership will require a shift away from autocratic and coercive modes to management by consent, with the urgent need to raise managerial capability for:

- conceptual and abstract thought

- an analytic approach to contemporary soci-political issues

- interpersonal persuasive and socio-political skills

- dealing with stress

- managing participatively in decentralized organizational structures.

A disturbing finding in Austin \& Ickis' Nicaraguan study which is relevant for South Africa, was that where essential human rights - such as freedom of association, the right of political organization and the exercise of a political franchise, are not achieved, there could be a further escalation of violent conflict, which upsets the supply of manpower for companies when factory workers and professional manpower are taken away from their regular jobs for military duty. This would present both serious moral dilemmas for individuals and a drain on technical and managerial talent in South Africa where management-worker ratios are estimated to be considerably higher than most industrialized countries at $1: 42$. The adverse impact on productivity levels is obvious. These pressures will be further aggravated by the fact that since July 1985 , South Africa has incurred a net loss of (mainly skilled) people. The disruption of traditional markets, shifting consumption patterns, scarcities of imported raw materials will necessitate readjustments of marketing and production strategies and processes. This could result in heightened feelings of insecurity amongst employees.

The crisis of employee expectations previously discussed presents not only potential threats to employers but also immense opportunities and challenges. Increased democratic co-operation through employee involvement and participation can be achieved, as well as new patterns of communication and ways of achieving multi-union and non-racial structures for collective bargaining and joint consultation. Senior managers will need to rethink and articulate the core values of their organization and develop pragmatic policies and implementable strategies. Managers will have to develop a greater social awareness. Corporate social responsibility should be accompanied by quality of work life programmes aimed at greater involvement of workers in work- and job-related decisions.

\section{Current initiatives}

It is contended that South Africa is essentially a free enterprise economy, albeit with a high degree of State intervention and regulation of numerous facets of the economy. Whilst definite benefits may occur in certain respects, the implications of current initiatives on deregulation and privatization which affect the socioeconomic position of employees, should be carefully considered, particularly in regard to measures which set minimum wages and conditions of employment. Wage rates negotiated by industrial councils and set by Wage Board determinations are in most cases below minimum living levels (MLL) for example in the security industry, when compared to the subsistance level figures researched by various universitities.

A recent survey of some 134 industrial council agreements conducted by The South African Labour and Development Research Unit (SALDRU 1986) indicates that only three exceed the University of South Africa calculated Supplementary Living Level (SLL). Sixteen industrial councils had minimum rates higher than the February 1986 MLL of R369 per month).

Most Industrial Councils (ICS) negotiate minimum wage levels rather than actual wages, frequently leaving flexibility for further increases and negotiated improvements at company or plant level. Industrial councils usually have a mechanism in their decision-making process which permit exemption from minimum wage rates (Horwitz, 1983:54). One of the criticisms of industrial councils by emergent trade unions is that wage minima are set on the basis of the lowest common denominator - that is, at the level which the smallest business which is a member of an employer association party to a council can afford. If most IC's are setting barely livable wage rates, it can be assumed that those who seek a removal or reduction in the level of minimum wage increases and exemption from IC agreements on the basis that they may affect the viability of their business, wish to pay 
wages which are probably likely to consign their employees to a sub-poverty existence. People employed under such circumstances are hardly likely to be profoundly productive or committed to a free enterprise system.

The Government has proceeded with a relaxation of regulations for small businesses, by permitting Wage Board determinations to exempt businesses which employ fewer than 15 people from minimum wage agreements (Business Day, March 7, 1986:2). The strategic implications and long-term social and political consequences of present stances on this issue should be carefully examined by employers, employer organizations and the State. Whilst for social and political reasons the economy under siege can neither afford to see further rises in unemployment nor poverty level wages, the achievement by employers and trade unions of a mutually acceptable balance between the inherent conflicts of wage cost increases, providing fuller employment, growth and profitability, presents a major challenge. What little credibility the free enterprise system has amongst black employees according to the findings of the Project on Free Enterprise (1986), would be further eroded if the proponents of free enterprise were to argue strongly in favour of measures which would result in the reduction of what in effect are mere poverty-level wages. It is submitted that the current debate on the survival of free enterprise, whilst necessary, is clouding several essential issues which must be urgently addressed. Such issues include the imperative to negotiate a socio-political and economic system which:

(a) addresses the question of power distribution and is visibly accepted by most people

(b) provides human rights such as the political franchise, and tangible benefits in respect of the quality of life and socio-economic development.

These benefits include fuller employment, greater job security, a living wage, upgraded and comfortable housing, equal non-racial education, equal physical, social and occupational mobility and social and medical care. However, Innes (1985) contends that 'Black people's experience of racial oppression in South Africa is closely linked to their experience of exploitation as workers. It might be apartheid laws which have restricted their freedoms, but it is the free enterprise system which has denied them a living wage.' Some contend that free enterprise, due to its ability to create wealth, is the economic system most likely to deliver 'tangible' benefits. This system with its legacy of support for apartheid has not had a good track-record on these issues in South Africa.

Laudably however, organized industry and commerce have taken strong oppositional stances against apartheid in recent years, arguably more out of enlightened selfinterest, than for ultruistic reasons. An alternative scenario is not unrestrained free enterprise, but a continued mixed economy with the possibility in the longer term of further nationalization of certain key industries and sectors, depending on the nature of developments in the political process.

(c) Addresses the dignity issue and provides equal opportunity for all South Africans. The new political and social order should therefore be free of racial discrimination and oppression.

(d) According to Crankshaw (1986:36) the fairness of the markets' distribution of created wealth will have to be addressed.

(e) Moves demonstrably towards a 'toenadering' or commonality of societal values and symbols but which also accomodates the independence of certain key interest groups such as trade unions.

The challenge facing human resource strategies in South Africa is not a stark choice between achieving a living wage and higher employment but in seeking a balance between equitable living wages, employment security, job creation and continued profitability. It is an immense challenge to say the least.

\section{Macro-level human resource strategies}

The role of employer organizations in the accomodation of conflict and in leading change is of paramount importance. Strategies need to be developed which reflect a move away from ad hoc responses to environmental problems and issues and greater unity of purpose and cohesion in spite of historical and ideological differences between employer organizations.

Douwes Dekker (1983) argues that employers' associations should not only perform the functions of collective bargaining, provision of advisory services to their members and influencing state bodies, but should also define social policy and action programmes, for example, in respect of housing. He added that, in the South African context, industrial councils offer considerable potential to provide a basis for implementing certain social policy objectives determined jointly between employers' associations and organized labour. 'Industrialisation,' states Douwes Dekker (1983) 'brings with it problems of an intensity and complexity which are best tackled through semi-state tripartite bodies. In Western Europe such advisory bodies developed to facilitate consultation and co-operation between public bodies and trade unions and employers' associations. The broad agenda of such bodies is to agree on socio-economic policy programmes to develop the economy, improve conditions of work, social security services and to raise the standard of living.'

Whilst the feasibility of seeking a common position between organized business and labour on economic policy is doubtful, there does appear to be a common objective in the removal of the apartheid system and on certain social issues.

\section{Unity of action}

This requires unity of action on the part of employers' associations to give expression to pragmatic social policy programmes and thereby match the emphasis by black unions on community involvement. This could be done jointly with trade unions.

Social policy agenda items may include social security funds, such as pensions, sick pay, medical benefits and at a macro-level, unemployment benefits. The paucity and 
weakness of social benefits provided by the state in many developing societies therefore necessitates greater cohesion and unity of strategy and action between employer associations, organized labour and the state, than seems to be the case in highly industrialized countries.

Large corporations should, according to Douwes Dekker, direct their resources to support the functions of employers' associations and should be involved in community affairs in conjunction with trade union leaders.

If the market-economy is to prevail in developing societies, the interactive role of employer organizations with labour and the state in respect of regional development plans and social programmes, should be recognised. The specific function of employer organizations in respect of a co-ordinated human resource strategy is a vital prerequisite for the institutionalization of conflict and prevailing power realities and attendant industrial stabilitv.

\section{Socio-economic and political functions of employer organizations}

According to Etheridge (1984), it is not appropriate to compare productivity indices of Third World countries with First World industrialized countries, or between these latter countries and others like South Africa, which is a mixture of First and Third Worlds.

When South Africa, for example, is compared with Third World countries, its Gross Domestic Product (GDP) is among the top countries. South African per capita GDP for 1980 was Rl 071. In comparison to that of Zambia (R298) and Kenya (R165) this is high. However, it does not compare favourably with the per capita GDP for most First World countries which was over R5 000 in 1980 .

The dualistic economy of South Africa and other developing economies is, however, inhibitive of successful competitiveness on international markets.

One of the major social responsibilities of the business sector and, by implication, organized employer organizations, is the supplementation of the state's efforts in respect of schooling, and general education, housing, health and welfare including providing social security schemes such as pensions. Van Coller (1983) argued, in this respect, that industry-based structures, such as industrial councils in South Africa comprising employer associations and trade unions, are more able than any other, to offer wide-ranging and comprehensive social benefit schemes to the largest possible number of employees.

In many African countries, including South Africa and Nigeria, a major proportion of the economically active population is employed in non-wealth producing public sector organizations. (In South Africa for example, some $30 \%$ of the economically active white population is employed by the state). Consequently the wealth generation process in developing countries rests with a small proportion of the population, who have the burden of generating sufficient wealth to sustain and increase state welfare services, education and health, and itself to be socially responsive in these and other areas, not to mention the immense challenge of job creation.

There is, therefore, a heavy burden in respect of the role of employers and employer organizations in developing societies.

Unlike in most First World societies, employer associations in developing societies such as Nigeria, the Sudan and South Africa have only recently begun to exert more overt and expressive lobbying activities with government in respect of influence on political, social and economic change. This lobbying and influencing function is an accepted major role of employer organizations is highly industrialized countries.

Greater co-ordination of strategy between various employer associations and organized industry as a whole is crucial and has only recently begun to emerge in South Africa (for example, the joint statement of the Federated Chamber of Industries) and other employer bodies in respect of their opposition to the detention without trial of trade union leaders.

\section{Training}

The crisis economy will be hard pressed to raise living standards and successfully compete on international markets. Considerable efforts need to be devoted to improving the general level of education and technical skills training of the population.

The development of co-ordinated training schemes on an industry specific basis, and sometimes across industries where certain common skills are required by various industries, is an important contributive opportunity for employer organizations.

Etheridge contends that developing countries will have to convert their workers to a First World level of training, expertise and productivity if international competitiveness is to be achieved. This is also crucial for economic growth, attendant job creation and improved living standards and prosperity.

However, organized industry cannot bear the task of achieving these goals alone. The influencing role of employer organizations with government has to be sufficiently impactful so as to achieve tangible changes in the relevant areas of government policy and statutes which affect the sociol and economic imperatives.

Labour and training legislation, effective manpower development and strategies for the effective utilization of national manpower resources, are crucial areas which necessitate employer organization influence on government.

\section{Business a corporate citizen}

According to Godsell (1986), business is a corporate citizen and therefore has a responsibility to exercise influence on decisions affecting its interests. It may be argued that organized business should play a role in the reform of structures of political power, particularly since successful political reform is more likely to occur with economic growth and growth is also more attainable with reform.

As any plural society reflects various conflict and 
power interests, there is a need for organized business to enter into dialogue and a dynamic interaction with interest groups such as political parties and organized labour on a regular basis.

Organized business has an important role to play in achieving a just society. Business engagement in the political arena should, therefore, be continuous and not merely issue related. Divisions within and between employer organizations reduces their influence on Government. Whilst some would argue that this influence is limited and this may well be so, the business sector cannot afford to be perceived by black employess as being tardy in this regard. The adverse consequences of employer passivity, to their credibility, and that of the free enterprise system, would be severe.

\section{Organizational strategies}

Operating in an economy of heightened uncertainty adds impetus to the need for organizational direction and identity. All individuals require a degree of psychological equilibrium to contribute to their own and their company's effectiveness. There are various organizational development approaches aimed at developing business effectiveness. However, the provision of a clearly articulated future direction is critical in order to maintain organizational cohesiveness and commitment amongst employees. The following are some fundamental requirements for an adaptive and responsive human resource strategy:

- An articulated, defined organizational philosophy or set of values about people which are known, understood and accepted by employees.

- Translation of these values into specific human resource policies and procedures.

- Development of strategies following an analysis of extra- and intra-organizational environmental demands which could be encountered over an identified period, and following an evaluation of threats and opportunities. The use of scenario planning is also helpful in this respect.

- Line managers from the interface level in the organization must participate in the process of developing strategies.

- Visible credible and visionary leadership and commitment from senior management.

- Action plans with line management responsibility for implementation and regular reviews of progress.

- The performance of the 'people values' must be reinforced by both intrinsic and extrinsic forms of reward.

The responsibility for effective human resource management must be built into line managers' and supervisors' job descriptions and performance appraisal and potential assesment schemes. Corrective and disciplinary action should be taken against employess who fail to effectively carry out the organization's human resource values and policies. The risks in the form of strikes, go. slows, and other forms of manpower withdrawal such as exessive absenteeism, are too high, particularly under highly uncertain and constrained economic and political circumstances, for organizations to tolerate poor human resource management.

\section{Conclusion}

In developing human resource strategies key issues should be identified, with attendant objectives. Employer approaches to the following issues will prove critical to their ability to adapt to change and their operational effectiveness in an uncertain, if not hostile, environment.

Institutionalization of inherent industrial conflict, as well as the pragmatic accommodation of conflict in local communities in order to seek a reduction in the disruption to the business. This means a willingness to enter into dialogue with local authorities and community organizations on issues affecting employees as well as greater participation by individual senior managers in influencing employer organization direction. Liaison and where necessary exerting pressure on authorities on issues affecting employees (e.g. rent problems) is vital. Employees should be given assistance with problems experienced in the community and employers should be more actively involved in improving the quality of life in local communities.

Individual employers can no longer avoid taking visible public stances on human rights issues affecting their businesses and which flout core values and progressive human resource policies. A failure to take a stand on these issues is likely to be perceived by employees as further collusion by employers with the apartheid system and therefore constitutes in itself, a political statement by the company.

Recently AECI Limited and the Premier Group have taken public stances in opposition to the detention without trail of trade union leaders. Civil disobedience by companies has been advocated by Reverend Sullivan in respect to opposition to discriminatory legislation (The Star, June 17, 1986). Some companies such as General Motors have in fact indicated that they will support employees charged with breaking apartheid laws.

Business should according to Dugard (1986) begin to pay more attention to taking up human rights violations in society in general and particularly in the work place. Employer approaches to increasing labour politicization are also crucial. It is postulated that these may substantively relate to the strategies of organized labour. If empathetic stances are taken towards worker demands which are perceived by employers as having legitimacy, and negotiated agreements are reached on sensitive issues such as May Day and June 16, less radicalization and greater willingness by trade unions to accept compromise could occur. Alternatively, reactionary responses such as mass dismissals, which reflect a perception of political issues such as stay-aways as illegitimate may well be associated with more acrimony and polarization in the work place.

The elimination of discriminatory practices such as separate facilities, discriminatory recruitment and selection and inadequate black advancement, is crucial. The 
ability of employers to change the present racial structure of the work place through expenditure on training, career development and advancement programmes, is also vital in order to reduce frustration and anger, and to achieve greater organizational commitment. Crucial in this regard is the need to address the issue of maintenance of employee dignity, and fairness in the work place, particularly at the critical supervisor-worker interface. Raising supervisory and managerial human resource management capability and performance must be urgently addressed.

Appropriate reward systems should be developed for superior performance in this area. Napier \& Peterson (1984:72) argue in this respect that line managers should be the principal 'human resource managers' of an organization.

As implementers of policy they are in a position to lead the progressive management of human resources. Human resource specialists should act as consultants to line managers, providing information and advice about various policies, procedures, techniques and methods to implement them.

Areas which require urgent research include perceptions of the changing managerial role in a siege economy with specific reference to variables such as organization culture, philosophy and structure, strategic thinking capability, leadership, industrial relations and socio-political awareness.

The siege economy and political laager will not dampen the aspirations and demands of those opposed to discrimination and injustice. The crises arising from siege and contradictions inherent in South African society can only intensify the complexity of the business environment. The expectations and demands of the majority of South Africans will continue to present a crucial challenge and opportunity for the business community to formulate radically new policy directions and innovative human resources strategies which seek to develop common values at all levels of society, an extension of democracy beyond our places of work, and sustained economic growth.

\section{References}

Austin, J.E. \& Ickis, J.C. June 1986. Managing after the revolutionaries have won. Harv. Bus. Rev., 103-108.

Beeton, J. 1986. Unemployment and job creation. IPM Manpower J., 22.

Crankshaw, R. July 1986. Privatisation : No answer for the masses. S. Afr. Labour Bull., vol. 11, 36.

D'Oliviera, J. July 1986. The Cost of punishing troublesome neighibours. The Argus, 14.
Douwes Dekker, L.C.G. 1983. Social Policy and the role of Employers Associations. S. Afr. J. Labour Rel., vol. 7, $41,43,45,53$.

Dugard, J. February 1986. Human Rights - the role of the Business Community. Address to AECI Industrial Relations Conference, Johannesburg.

Etheridge, D. December 1984. South Africa: The unproductive Society. SA Institute of Race Relations, Topical Opinion, Johannesburg, 1-2, 4-8.

Godsell, R.M. February 18 ,1986. Business and Politics. An address to the South African Institute of Race Relations, Johannesburg.

Horwitz, F.M. October 7, 1983. Focus on Industrial Councils. Financial Mail, 54.

Industrial Council Wage Rates. Ist Quarter 1986. Southern Africa Labour Development Research Unit (SALDRU) Quarterly Review, University of Cape Town.

Innes, D. 1986. A gale blows across the free enterprise bathtub. Weekly Mail, 16-19 June, 2.

Kantor, B. 1986. The current state of the economy and the siege economy. Address to Cape Chamber of Commerce, July 29.

Labour Monitoring Group. 1986. Report in Financial Mail, July $11,48$.

Leatt, J. 1984. Corporate Responsibility and South Africa's Political Economy. Inaugural Lecture Series, no. 98, October 17, University of Cape Town, 1.

Napier, N. \& Peterson, R. 1984. Putting Human Resource Management at the Line Manager Level. Bus. Hor., vol. 27, 72.

Nel, C. (Project Leader) 1986. Economic Participation in South Africa. Project Free Enterprise Report. University of South Africa, Pretoria, 24-25.

Nel, C. 1986. Sanctions threaten a million. Sunday Times, Business Times, July 7, 1.

Ooosthuizen, A. 1986. Up to 10 million urban blacks by 2000 . The Star, June 17, 7.

Report on South African Labour Statistics, 1986. Central Statistical Services, Pretoria, xxi.

Sullivan, L.(Rev) 1986. Quoted in The Star, June 17, 13.

The Argus, July 2, 1986. Editorial. 14.

Uys, S. 1986. Why is big business foresaking reform? Business Day, August 28, 6 .

Van Coller, S. 1983. Taks vital to prevent unrest. Engineering Week, November 10, 3.

Van der Watt, A.J. 1983. Industrial Relations Post Wiehahn. Address to SA Intitution of Mechanical Engineers, Johannesburg.

Van Zyl-Slabbert, F. 1986. Address at Master of Business Administration(MBA) Annual Dinner, July 23. University of Cape Town. 